DOI: $10.2478 / \mathrm{v} 10047-011-0028-3$

PHYSICAL AND TECHNICAL PROBLEMS OF ENERGETICS

\title{
ANALYSIS OF FLUE GAS CONDENSER OPERATION
}

\author{
D. Blumberga, E. Vigants, I. Veidenbergs \\ Institute of Energy Systems and Environment, \\ Riga Technical University, \\ 1 Kronvalda Blvd., Riga, LV-1010, Latvia
}

\begin{abstract}
The paper is devoted to the problems connected with the use of gas condensers in the wood chips-fuelled boilers. To process the relevant data and evaluate the operation of such a gas condenser, a model was created which involves not only the data derived from performance calculations of the energy source but also the data of experimental measurements; besides, the model contains an evaluation module which allows the efficiency of a gas condenser's operation and the necessary improvements to be determined.

Key words: gas condenser, chip-fuelled/hog fuel boiler, condensation, evaporation, physical heat of flue gases, energy efficiency
\end{abstract}

\section{INTRODUCTION}

The challenge facing the EU member-states is the $20 \%$ increase in the specific weight of renewable energy resources by 2020 . To achieve this goal an important role is assigned to the efficient use of power-generating wood fuel - an issue of not only technological, economic and socio-economic significance but also as considered from the viewpoint of environment protection and global climate change.

One of the most widely spread wood fuels is chips or hog fuel, which is easy to prepare, transport and use with a high output in the energy sources.

The efficiency of chip combustion depends on the quality of initial fuel as well as on the efficiency of combustion process and heat utilisation. The wetter the hog fuel, the more heat is consumed in the combustion process for water evaporation and vice versa. The set of all these questions as related to operating the chip-fuelled boilers is to be solved using the following approaches:

- Increase in the fuel quality - in European Union the standards have already worked out that impose limits on the moisture content of wood fuel; in particular, the moisture content of chip (hog) fuel must not exceed $25 \%$.

- Utilisation of the heat generated in condensation of flue gas vapours thus raising the efficiency of energy sources when using wet chips. For this purpose it is necessary to install special units (so-called gas condensers) for condensation of vapours contained in flue gases.

The issues of energy effective utilisation of hog fuel are gradually passing from the sphere of making and operating the boilers to that of seeking solutions for efficient operation of a power system as the whole. In particular, the problems of 
flue gas deep cooling are connected with the necessity to integrate a large number of low-potential heat consumers - not only in a heat supply system but in the technological scheme of any industrial enterprise [1-3].

It is therefore important to evaluate not only the heat energy parameters but also complex heat-and-mass exchange processes in a gas condenser, which are intricate and proceed simultaneously: the heat exchange by radiation, convection, and conduction, as well as absorption, evaporation and condensation. The simultaneity and interaction of all these processes in combination with various factors influencing the amount of energy produced - all this adds complexity when designing the required equipment and defining its parameters [4-6]. This explains the great variety of devices intended to raise the efficiency of energy resources.

At the boiler-house of the Ludza city's district heating system a pilot experimental set is installed; it is designed to be operated in the cases with and without a filling (normally used to increase the surface for condensation of vapour from flue gases).

\section{DESCRIPTION OF THE COMMERCIAL EXPERIMENT}

The experiment (based on the experience acquired at monitoring and control of the contact heat exchangers with active filling [7]) was run on a commercial scale, with the use of measuring devices to determine the efficiency of an energy source's operation with and without a flue gas condenser as well as with and without filling in it. The condenser consists of two series-connected heat-and-mass exchangers. The main function is allocated to the horizontal gas channel, in which at the gas flow centre special slits for drizzling liquid outlet are made; in this channel, both the directions of heat carriers coincide. In the other part, a countercurrent flow of heat carriers is organised in which the flue gases with elevated vapour content descend to the condenser's lower tank and are let out from its upper part. In the vertical section a partial evaporation and condensation (in drops of drizzling liquid) occur. The mixture of condensate and drizzling liquid ascend to the condenser's upper tank, from which it is fed to the heat system's exchanger in order to cool it. The measuring circuit is shown in Fig. 1.

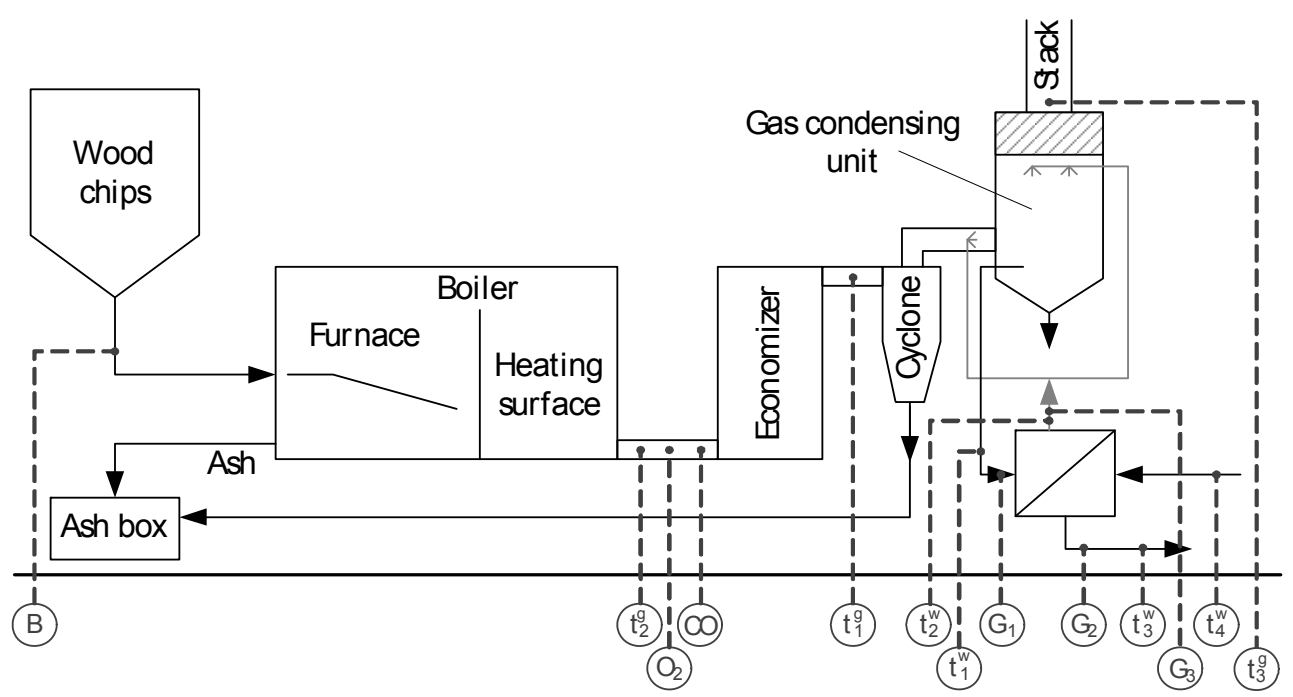

Fig.1. The scheme of experimental investigation. 
The parameters measured in the commercial experiment and the relevant units are presented and clarified in Table 1.

The parameters measured in the experiment

\begin{tabular}{|c|c|l|}
\hline Designation & $\begin{array}{c}\text { Measurement } \\
\text { unit }\end{array}$ & \multicolumn{1}{|c|}{ Parameter } \\
\hline $\mathrm{B}$ & $\mathrm{kg} / \mathrm{h}$ & Fuel consumption \\
\hline $\mathrm{O}_{2}$ & $\%$ & Oxygen concentration in the flue gases \\
\hline $\mathrm{CO}$ & $\mathrm{ppm}$ & Carbon monoxide concentration in the flue gases \\
\hline $\mathrm{G}_{1}$ & $\mathrm{~kg} / \mathrm{s}$ & $\begin{array}{l}\text { Flow of condensate and drizzling water mixture through the } \\
\text { heat system's exchanger }\end{array}$ \\
\hline $\mathrm{G}_{2}$ & $\mathrm{~kg} / \mathrm{s}$ & The heat system's water flow through the heat exchanger \\
\hline $\mathrm{G}_{3}$ & $\mathrm{~kg} / \mathrm{s}$ & Outflow of drizzling water through slits \\
\hline $\mathrm{t}_{1}{ }^{\mathrm{w}}$ & ${ }^{\circ} \mathrm{C}$ & $\begin{array}{l}\text { Temperature of the condensate and drizzling water mixture } \\
\text { upstream of exchanger }\end{array}$ \\
\hline $\mathrm{t}_{2}{ }^{\mathrm{w}}$ & ${ }^{\circ} \mathrm{C}$ & $\begin{array}{l}\text { Temperature of the condensate and drizzling water mixture } \\
\text { downstream of exchanger }\end{array}$ \\
\hline $\mathrm{t}_{3}{ }^{\mathrm{w}}$ & ${ }^{\circ} \mathrm{C}$ & $\begin{array}{l}\text { Temperature of the heat system's water downstream of } \\
\text { exchanger }\end{array}$ \\
\hline $\mathrm{t}_{4}{ }^{\mathrm{w}}$ & ${ }^{\circ} \mathrm{C}$ & Temperature of the heat system's water upstream of exchanger \\
\hline $\mathrm{t}_{1}{ }^{\mathrm{g}}$ & ${ }^{\circ} \mathrm{C}$ & Temperature of flue gases upstream of the gas condenser \\
\hline $\mathrm{t}_{2}{ }^{\mathrm{g}}$ & ${ }^{\circ} \mathrm{C}$ & Temperature of flue gases downstream of the boiler \\
\hline $\mathrm{t}_{3}{ }^{\mathrm{g}}$ & ${ }^{\circ} \mathrm{C}$ & Temperature of flue gases downstream of the gas condenser \\
\hline
\end{tabular}

The measurements performed in the experiment could be divided into three groups:

- The efficiency of fuel combustion and heat exchange is determined by measuring the temperatures of gases and making their analysis.

- The efficiency of gas condenser operation is evaluated by measuring the heat carrier temperatures at the inlet and outlet and by defining the flow of both the carriers (flue gases and the mixture of condensate and drizzling liquid) that arise in the heat-and-mass exchange process.

- The efficiency of the heat system's exchanger at operation is analysed by measuring the temperatures and flows of both heat carriers at the inlet and outlet, with one of the heat carriers being a mixture of condensate and drizzling liquid that was in contact with flue gases, while the other - the heat system's water that through the exchanger's wall receives heat from the mentioned mixture.

\section{THE MODEL FOR DATA TREATMENT AND PERFORMANCE EVALUATION}

The model created for data treatment and performance evaluation of a gas condenser involves the data necessary for calculations of an energy source's operation, the data and analysis of experimental measurements, and an evaluation module meant for determination of gas condenser's operation efficiency, allowing the necessary improvements to be made. 
The block-diagram of the model for data treatment and performance evaluation is displayed in Fig. 2.

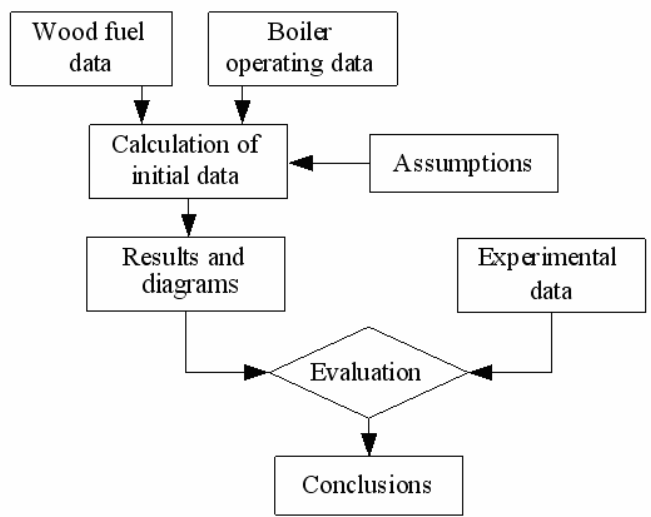

Fig. 2. The block-diagram of the model for data treatment and performance evaluation.

The model for data treatment and performance evaluation consists of a module for the wood fuel and boiler operating data, a module for calculation of the initial data, and the evaluation module proper. By means of this module the results can be compared with those obtained experimentally, which makes it possible to analyse not only the results obtained for the gas condenser but also to model the potential gains in the case of efficiency improvement achieved.

\section{MODELLING RESULTS}

The amount of heat recovered from flue gases in the gas condenser is determined from the balance equation:

$$
Q_{g c}=Q_{c}+Q_{p h}, \mathrm{MWh},
$$

where: $Q_{g c}$ is the heat recovered in the gas condenser, $\mathrm{MWh}$;

$Q_{c}$ is the vapour condensation heat recovered in the gas condenser, $\mathrm{MWh}$;

$Q_{p h}$ is the recovered physical heat of flue gases, MWh.

The heat received in the condensation process in the condenser is obtained in dependence on the moisture content of chips from the equation:

$$
Q_{c}=B_{d} \cdot W^{w} \cdot h \cdot \frac{g}{100-W^{w}}, \mathrm{MWh}
$$

where: $B_{d}$ is the consumption of working fuel dry mass, t;

$W^{w}$ is the moisture content of working fuel, \%;

$g$ is the intensity of vapour condensation process;

$h$ is the heat of vapour condensation, MWh.

The intensity of condensation process depends not only on how the process is arranged in a gas condenser but also on the moisture content of the wood, the quality of combustion process and the parameters of flue gases at the gas con- 
denser's inlet. The heat energy recovered from flue gases is most often in the 30 $100 \%$ range.

The main factors affecting the physical heat of flue gases that could be utilised in a gas condenser are: the temperature of flue gases, their volume, and the moisture content of wood:

$$
Q_{p h}=B \cdot\left(H_{f g 1}^{0}-H_{f g 2}^{0}\right)+(a-1) \cdot\left(H_{a 1}^{0}-H_{a 2}^{0}\right), \mathrm{MWh},
$$

where: $B$ is the consumption of working fuel, $\mathrm{t}$;

$a$ is a coefficient of air consumption;

$H_{f g 1}^{0}$ is the stoichiometric enthalpy of combustion process at the inlet of the gas condenser, $\mathrm{MWh} / \mathrm{kg}$;

$H_{f g 2}^{0}$ is the stoichiometric enthalpy of combustion process at the outlet of the gas condenser, $\mathrm{MWh} / \mathrm{kg}$;

$H_{a 1}^{0}$ is the enthalpy of air volume theoretically required for the fuel combustion at the inlet of the gas condenser, $\mathrm{MWh} / \mathrm{kg}$;

$H_{a 2}^{0}$ is the enthalpy of air volume theoretically required for the fuel combustion at the outlet of the gas condenser, $\mathrm{MWh} / \mathrm{kg}$.

\section{EXPERIMENTAL RESULTS}

The first experimental data obtained within a month for an empty gas condenser (i.e. without filling) are shown in Figs. 3, 4, and 5.

The regression analysis of the data on the total specific heat recovered in a gas condenser in dependence on the boiler capacity (Fig. 3) shows a poor correlation of the data. The wide scatter in them is evidence for a significant influence of some other factors on the amount of heat recovered in the gas condenser, e.g. the moisture content of wood, the flow of flue gases, their temperature, and others.

At the same time, a tendency could be seen that the heat output is decreasing with a boiler's load increasing. This is explainable with limitations of a condensation process and the necessity for filling in order to increase the condensation surface.

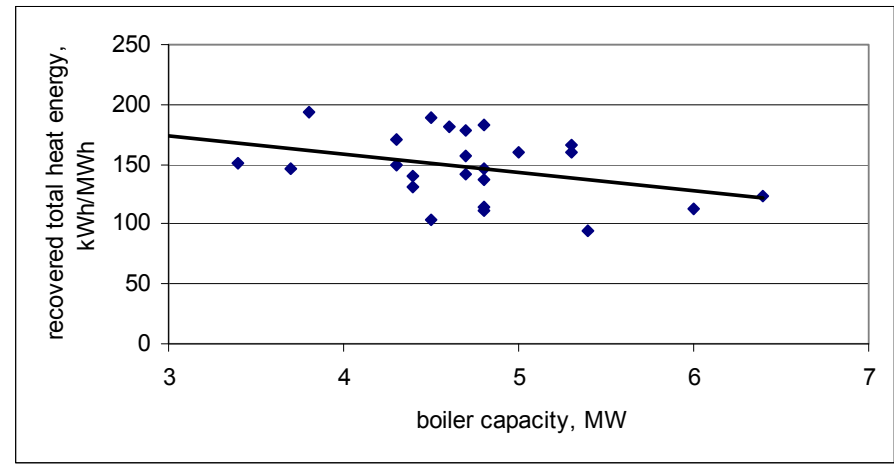

Fig. 3. The total specific heat recovered in the gas condenser $v s$. the boiler capacity. 
The data interpretation is further given in Figs. 4 and 5, which show separately the role of both the components - the physical heat of flue gases and the heat of vapour condensation - in the heat-and-mass exchange proceeding in an empty gas condenser.

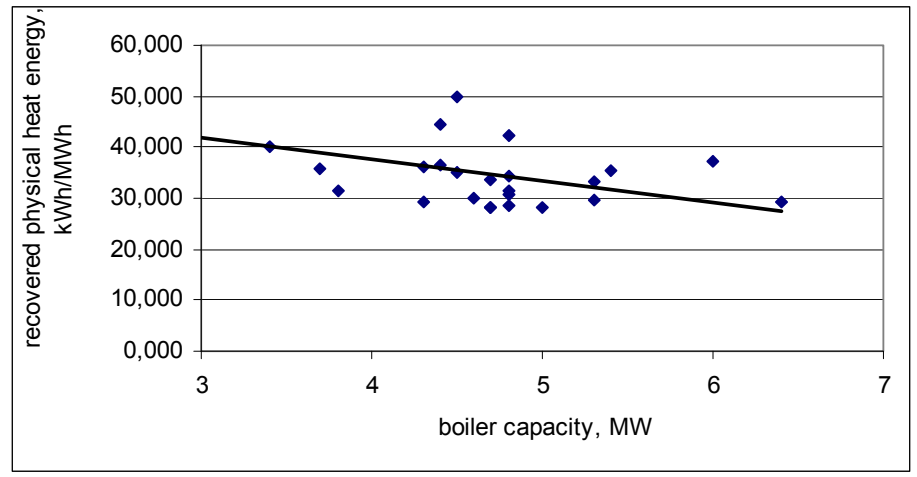

Fig. 4. The specific physical heat recovered in the gas condenser $v s$. the boiler capacity.

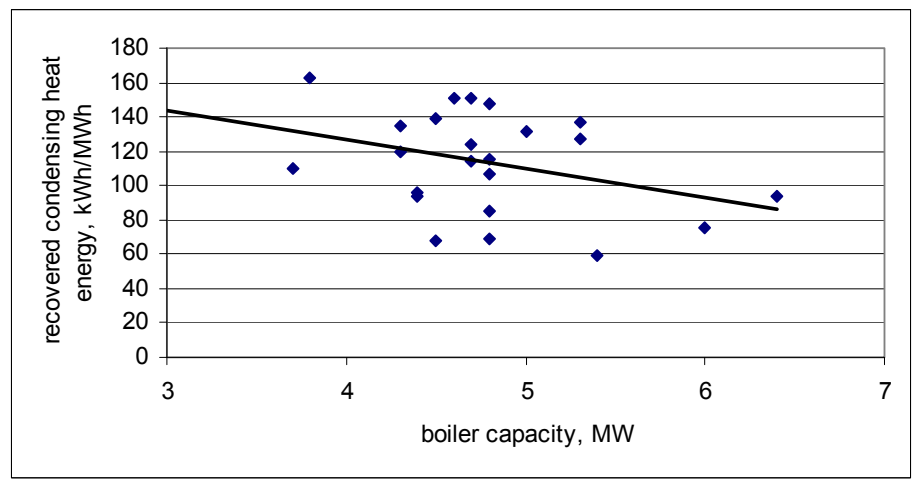

Fig. 5. The specific condensation heat recovered in the gas condenser $v s$. the boiler capacity (the line corresponds to the empirical model).

The regression analysis of the data on the specific physical heat recovered in the gas condenser in dependence on the boiler capacity (Fig. 4) shows a better data correlation as compared with those in Fig. 3 as well as in Fig. 5 below. However, this correlation is not quite satisfactory $(R 2=0.41)$. Therefore, the empirical model is employed to characterise the tendency observed in the dependence of the specific physical heat of flue gases obtained in the gas condenser on the boiler load. This heat could be described as

$$
q=-4.1655 Q_{b}+54.241, \mathrm{kWh} / \mathrm{MWh},
$$

where $Q_{b}$ is the capacity of a chip-fuelled boiler, MW.

The wide data scatter evidences that there is a significant influence of some other heat-and-mass exchange parameters on the specific physical heat recovered in a gas condenser: the flow of flue gases through this condenser, their temperatures at its inlet and outlet, etc.. 
In turn, the regression analysis has been performed for the data on the specific condensation heat recovered from flue gas vapours in the gas condenser in dependence on the boiler capacity (Fig. 5), which shows a worse data correlation as compared with the straight line in the empirical model.

In this last case the causes of scatter are associated not only with the factors mentioned above in connection with the results of studying the heat-and-mass exchange processes and concerning the specific physical heat of flue gases obtained in the gas condenser; the intensity of vapour condensation is also affected by the drizzling liquid parameters: temperature, size of drops on which the vapour condensation occurs, the movement velocity of the condensate drops, and other factors.

The tendency confirmed by the regression analysis is that the output falls with increasing load of a boiler, with acceleration of flue gases in the apparatus, and with decreasing time of their contact with the condensation surface (a drop of liquid). This means that optimal conditions could be found for the condensation process in an empty gas condenser of available design.

\section{CONCLUSIONS}

Conclusions that could be drawn based on the results of our experiment are as follows.

1) The data obtained for an empty gas condenser installed after a chipfuelled boiler show that in this case it is possible to receive heat energy in the amount of $100-180 \mathrm{kWh} / \mathrm{MWh}$.

2) In a gas condenser the complicated heat-and-mass exchange processes occur simultaneously: "dry" exchange by radiation, convection, and heat conduction, as well as evaporation and condensation. The experimental results evidence that the obtained physical heat component is smaller than the thermal energy received in the condensation process.

3) A tendency is observed that the total specific heat received in a gas condenser is decreasing as the boiler's load increases. This is connected with limitations of the condensation process and the necessity to use a filling in order to increase the condensation surface.

4) The dependence of changes in the specific heat output on the boiler's load proves that the energy efficiency of an empty gas condenser suffers from the existing design and heat supply system limitations.

\section{REFERENCES}

1. Wang, L. (2009). Energy Efficiency and Management in Food Processing Facilities. CRC Press, $452 \mathrm{p}$.

2. Smejkal, D., Sarlej, M., \& Stehlik, P. (2009). New unit for clean energy production from contaminated biomass $\left(1\right.$ to $\left.3 \mathrm{MW}_{\mathrm{t}}\right)$ - examples of process design. J. Chemical Engineering Transactions, 8, 57-63.

3. Blumberga, D., \& Veidenbergs, I. (1996). Energ̊etiskās koksnes izmantošanas energoefektivitātes un ekolog̣isko jautājumu mijiedarbība. Latv. J. Phys. Techn. Sci., (3), (in Latvian). 
4. Blumberga, D., Veidenbergs, I., Kass, I., Blumberga, A., \& Bokta, H. (1995). Improving Energy Efficiency: the Supply Side Approach Lessons. Sustainability and the Reinvention of Government. Proceedings ECEEE, Summer Study, June 5-9. Mandeleau.France Panel1- ID44.

5. Val'dberg, A.Y., \& Zhigun, O.V. (2008). Designing hollow spray scrubbers for evaporative gas cooling. J. Chemical and Petroleum Engineering, 44, 67-72.

6. Val'dberg, A.Yu., Kuzina, T.N., \& Bykova, Yu.V. (2009). Calculating the heights of a standard series of scrubbers working with complete evaporation of the irrigating liquid. J. Chemical and Petroleum Engineering, 45, 500-504.

7. Blumberga, D. (1996). Energoefektivitāte. Pētergailis (in Latvian).

\section{GĀZES KONDENSATORA DARBĪBAS ANALĪZE}

D. Blumberga, E. Vīgants, I. Veidenbergs

\section{Kopsavilkums}

Koksnes šķeldas izmantošanas efektivitātes paaugstināšanas iespējas ir dažādas: ne tikai tās mitruma samazināšana, bet arī tvaiku kondensācijas siltuma atgūšana gāzes kondensatoros. Rakstā pētītas problēmas, kas ir saistītas ar gāzes kondensatora izmantošanu šķeldas katlu mājās. Izstrādātais datu apstrādes un gāzes kondensatora darbības vērtēšanas modelis ietver gan datus, kas ir iegūti no energoavota darbības aprēķiniem, gan eksperimentālu mērījumu datus un analīzi, gan arī vērtēšanas moduli, ar kura palīdzību ir iespējams noteikt gāzes kondensatora iekārtas darbības efektivitāti un potenciālos uzlabojumus.

Eksperimentālo datu apstrādes rezultātā iegūts empīrisks modelis, kas liecina, ka pieaugot katla jaudai, samazinās īpatnējais iegūtā siltuma daudzums, kas liecina par tukša gāzes kondensatora darbības energoefektivitātes konstruktīviem un siltumapgādes sistēmas ierobežojumiem. Iegūtie rezultāti apliecina, ka iegūtā fiziskā siltuma komponente ir mazāka par kondensācijas procesā saņemto siltumenerğiju.

10.08.2011. 